\title{
Upaya Pencegahan Penyebaran Virus Covid-19 Di Kelurahan Lirboyo Kota Kediri
}

\author{
Agata Iwan Candra*, Sony Santoso, Hendy, Rekso Ajiono, Fauzie Nursandah \\ Fakultas Teknik Universitas Kadiri \\ *E-mail : Iwan_candra@unik-kediri.ac.id \\ DOI: https://doi.org/10.21107/pangabdhi.v6i2.7395 \\ Naskah diterima 23 Juli 2020, Revisi 7 September 2020, Terbit 29 Oktober 2020
}

\begin{abstract}
Abstrak
Pada akhir Maret 2020, jumlah Orang Dalam Pemantauan (ODP) di Kota Kediri mencapai 46 orang, sedangkan jumlah Pasien Dalam Pengawasan (PDP) dan positif COVID-19 masing-masing satu orang. Lirboyo adalah salah satu kelurahan di wilayah Kecamatan Mojoroto, Kota Kediri. Pada kelurahan ini terdapat Pondok Pesantren Lirboyo. Pondok Pesantren merupakan salah satu tempat dengan tingkat kepadatan yang cukup tinggi dan tingkat kebersihan yang cukup rendah. Hal ini menjadikan Kelurahan Lirboyo rentan terhadap penyebaran virus COVID-19. Melalui kegiatan Pengabdian Masyarakat Fakultas Teknik Universitas Kadiri, telah berhasil dilaksanakan pembagian masker, hand soap dan hand sanitizer serta bahan makanan berupa beras. Selain itu dilakukan sosialisasi pencegahan penyebaran virus COVID-19 dan upaya penyediaan wastafel portable dan ruang Mudroom atau ruang depan antara pintu depan dan rumah, yang merupakan tempat ideal untuk melepas sepatu, menggantung jaket, membersihkan tangan sebelum melangkah masuk ke wilayah rumah. Hasil kegiatan pengabdian masyarakat ini menunjukkan antusias masyarakat Kelurahan Lirboyo dan perlunya kegiatan intensif lanjutan.
\end{abstract}

Kata Kunci: Covid-19, upaya pencegahan, mudroom, sosialisasi

\begin{abstract}
At the end of March 2020, the number of Monitoring Persons (ODP) in the City of Kediri reached 46 people, while the number of Patients Under Monitoring (PDP) and positive COVID-19 were only one person each. Lirboyo is one of the villages in the Mojoroto Subdistrict, Kediri City. In this village located the Lirboyo Islamic Boarding School. Pondok Pesantren is one place with a high level of density and a fairly low level of cleanliness. This makes Lirboyo vulnerable to the spread of the COVID-19 virus. Through the community service activities, Faculty of Engineering Kadiri University distributed masks, hand soap and hand sanitizers and food. In addition, socialization was carried out to prevent the spread of the COVID-19 virus to provide a portable sink and mudroom or front room between the front door and the house, which is an ideal place to take off shoes, hang a jacket, clean hands before stepping into the home area. From the results of this activity it can be seen that the enthusiasm of the lirboyo village community and the need for further socialization activities.
\end{abstract}

Key Words : Covid-19, prevention efforts, mudroom, socialization

\section{PENDAHULUAN}

Virus Corona atau Severe Acute Respiratory Syndrome Corona Virus 2 (SARS-Cov-2) merupakan salah satu jenis virus yang menyerang system pernafasan. Virus ini merupakan jenis baru dari Corona virus yang menular ke manusia. Infeksi virus Corona Covid19 pertama kali ditemukan di Kota Wuhan, China pada akhir Desember 2019. Virus ini menular dengan sangat cepat dan telah menyebar ke hampir semua negara maju seperti Amerika Serikat dan negara-negara Eropa dan negara- negara berkembang termasuk Indonesia. Penyebaran yang sangat cepat ini membuat banyak negara menerapkan kebijakan pemberlakuan lockdown. Di Indonesia sendiri, terutama di ibukota Jakarta telah diberlakukan kebijakan pembatasan sosial berskala besar (PSBB).

Kota Kediri termasuk dalam Karasidenan Kediri dan merupakan salah satu kota terbesar di Karasidenan tersebut. Kediri memiliki luas area $63.4 \mathrm{~km} 2$, dan merupakan kota yang kian berkembang (Hendy et.al, 2018). Pada tanggal 
28 Maret 2020, Wali kota Kediri yaitu Bapak Abdullah Abu Bakar, mengumumkan kasus positif virus corona pertama di wilayah Kota Kediri. Dengan adanya kasus positif corona tersebut, maka Kota Kediri termasuk dalam kawasan zona merah. Di akhir Maret 2020 tersebut, jumlah Orang Dalam Pemantauan (ODP) di Kota Kediri mencapai 46 orang. Sedangkan jumlah Pasien Dalam Pengawasan (PDP) dan positif COVID-19 masing-masing satu orang.

Beberapa upaya telah dilakukan di berbagai daerah dalam mencegah penyebaran virus COVID-19 salah satunya adalah sosialisasi perilaku hidup bersih dan sehat (PHBS) pada anak usia dini di RA Lab-School IAIN Pekalongan (Tabi'in, 2020). Selain itu, Zukmadini (2020) telah melakukan edukasi perilaku hidup bersih dalam pencegahan COVID-19 kepada anak-anak di panti asuhan. Herlan dkk di tahun 2020 juga telah menunjukkan keterlibatan akademisi dalam menanggulangi dampak COVID-19 terhadap masyarakat melalui aksi berbagi sembako. Fitriasari di tahun 2020 juga telah melakukan pencegaan primer dalam upaya membentuk masyarakat sehat di era COVID-19. Sementara itu, Syafrida dan Hartati (2020) mengungkapkan perlunya kerjasama pemerintah, masyarakat dan tokoh agama dalam menghadapi COVID-19.

Lirboyo adalah salah satu kelurahan di wilayah Kecamatan Mojoroto, Kota Kediri. Di kelurahan ini terdapat Pondok Pesantren Lirboyo, dimana seperti yang kita ketahui, Pondok Pesantren merupakan salah satu tempat dengan tingkat kepadatan yang cukup tinggi dan tingkat kebersihan yang cukup rendah. Hal ini memerlukan upaya yang intensif dalam mensosialisasikan upaya-upaya pencegahan penularan virus COVID-19 di wilayah kelurahan Lirboyo Kecamatan Mojoroto Kota Kediri.

\section{METODE}

Kegiatan ini dirancang sebagai respon cepat atas pandemi Covid-19 yang sedang terjadi, terutama di daerah sekitar Universitas Kadiri yaitu Kelurahan Lirboyo. Dari hasil mengidentifikasi keadaan di Kelurahan Lirboyo, tim pengabdian masyarakat Fakultas Teknik Universitas Kadiri melaksanakan kegiatan dalam tiga tahapan yaitu: tahap persiapan, tahap pelaksanaan, dan tahap monitoring.

Pada tahap persiapan yang dilakukan pada tanggal $7-20$ April 2020, tim pengabdian masyarakat melakukan survey lokasi tempat tujuan pengabdian masyarakat, tepatnya di Kelurahan Lirboyo. Pada tahapan ini tim pengabmas lebih banyak mendengar tentang kondisi masyarakat Kelurahan Lirboyo dan kegiatan-kegiatan apa saja yang telah terlaksana dan belum terlaksana secara optimal di kelurahan tersebut. Selain itu, pada tahapan ini, tim pengabdian masyarakat juga berupaya menghimpun dana dari beberapa kalangan yaitu sivitas akademik Universitas Kadiri yang terdiri dari staf dan dosen, juga dari kalangan alumni dan bantuan dari Universitas Kadiri. Dana yang terkumpul dimanfaatkan sepenuhnya untuk pengadaan bahan makanan berupa sembako dan alat kesehatan yang dibutuhkan seperti masker, hand sanitizer dan hand soap.

Setelah melakukan tahapan persiapan, selanjutnya tim pengabdian masyarakat melakukan tahapan pelaksanaan yaitu dengan melakukan sosialisasi upaya-upaya pencegahan penyebaran virus COVID-19, pembagian sembako dan peralatan kesehatan. Upaya pencegahan penyebaran virus COVID 19 di Kelurahan Lirboyo Kota Kediri dilaksanaakan pada hari Senin 21 April, dengan sasaran kegiatan adalah warga keluarahn lirboyo dan para petugas yang berada di Kelurahan Lirboyo.

Dua minggu setelah tahapan pelaksanaan, Ketua tim pengabdian masyarakat terus menjalin komunikasi untuk memonitpr informasi perkembangan penyebaran virus COVID-19 di Kelurahan Lirboyo Kota Kediri. Hal ini merupakan wujud kerjsama antara Fakultas Teknik Universitas Kadiri dengan masyarakat setempat.

\section{HASIL DAN PEMBAHASAN}

Kegiatan ini dilakukan sebagai wujud respon cepat terhadap pandemic Covid-19. Kegiatan sosialisasi dan pembagian alat pelindung diri ini dilaksanakan di Kelurahan Lirboyo Kecamatan Mojoroto, dengan sasaran adalah mayarakat di titik-titik ramai di kawasan kelurahan Lirboyo. Secara umum, langkah kegiatan dimulai dari sosialisasi pencegahan penularan virus COVID19 yaitu dengan melakukan:

1. Mencuci tangan secara rutin dengan gel atau sabun pembersih yang kemudian dibilas dengan air bersih, atau dengan hand sanitizer berbasis alkohol.

2. Menutup hidung dan mulut dengan menggunakan masker. Batuk dan bersin pada 
bagian dalam siku (memperhatikan etika bersin dan batuk).

3. Menghindari interaksi fisik (menjaga jarak 1 meter atau 3 kaki) atau lebih dikenal dengan istilah "Physical Distancing."

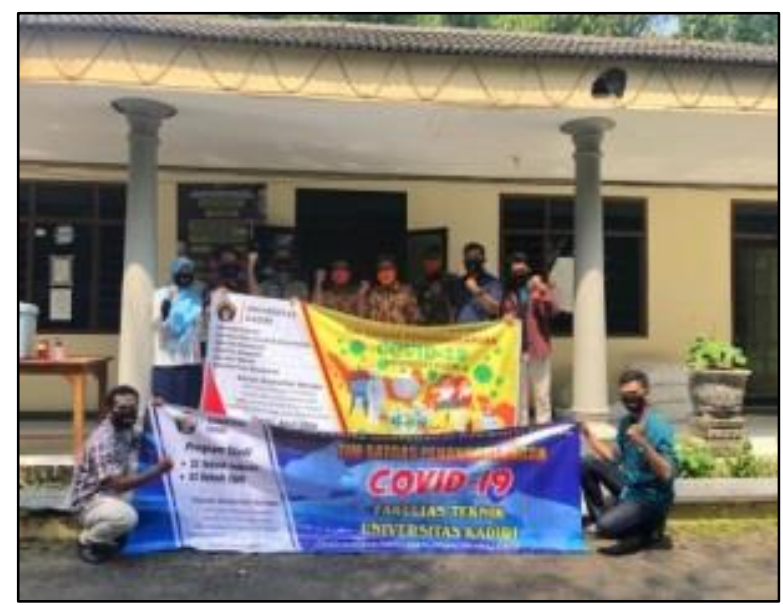

Gambar 1. Sosialisasi Kegiatan di Kelurahan Lirboyo Kota Kediri

Selain mensosialisasikan upaya pencegahan penularan virus COVID-19 diatas, dilaksanakan pula pembagian masker, sabun pembersih tangan, hand sanitizer dan bahan pokok berupa beras (Gambar 2). Selain hal tersebut diatas, melalui staf kelurahan, Ketua pelaksana Kegiatan Pengabdian Masyarakat akan menginformasikan dan menghimbau untuk melakukan penyediaan wastafel/tempat cuci tangan portable di area depan rumah warga. Hal ini bertujuan untuk mengingatkan warga Kelurahan Lirboyo agar sering melakukan cuci tangan.

Hasil yang sudah dicapai pada kegiatan pengabdian masyarakat ini adalah:

- Pada Tahapan Persiapan, tim pengabdian masyarakat telah berhasil menghimpun dana dari sivitas akademik Universitas Kadiri, sumbangan Universitas dan alumni.

- Pada tahap pelaksanaan, tim pengabdian Masyarakat Fakultas Teknik Universitas Kadiri telah melakukan sosialisasi upayaupaya pencegahan penularan virus COVID-19 dan pengenalan penggunaan wastafel portable dan Mudroom. Selain itu, tim pengabdian Masyarakat Fakultas Teknik Universitas Kadiri telah melakukan pembagian masker, hand sanitizer dan sabun pencuci tangan dan bahan makanan pokok berupa beras yang sangat dibutuhkan oleh masyarakat Kelurahan Lirboyo.

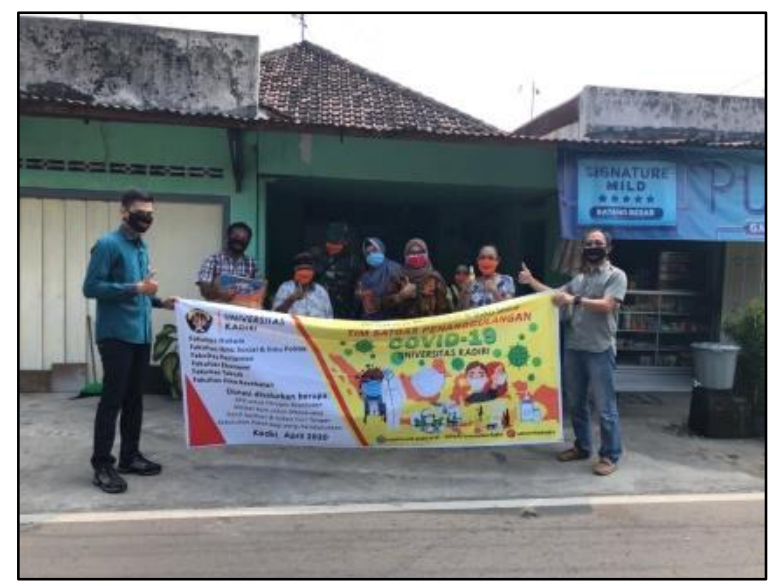

Gambar 2. Dokumentasi Pembagian Masker, Hand Sanitizer, Hand Soap dan Sosialisasi Pada Warga Kelurahan Lirboyo

\section{KESIMPULAN}

Dari pelaksanaan kegiatan ini terlihat respon positif dan antusias warga Kelurahan Lirboyo Kecamatan Mojoroto Kota Kediri. Rekomendasi dari hasil kegiatan ini adalah pelaksanaan kegiatan lanjutan untuk memantau dan lebih meningkatkan kesadaran masyarakat dalam pelaksanaan upaya pencegahan penularan virus Corona Covid-19. Selain itu Beberapa hal yang perlu diperhatikan dalam masa penyebaran virus COVID-19 ditinjau dari tata ruang rumah yaitu:

1. Sebaiknya dipertimbangkan untuk menyediakan Mudroom atau ruang depan antara pintu depan dan rumah, yaitu tempat yang ideal untuk melepas sepatu, menggantung jaket, membersihkan tangan sebelum melangkah masuk. Peningkatan fokus untuk menciptakan pintu masuk yang bersih dan terorganisir sehingga dapat membersihkan diri sebelum memasuki rumah.

2. Lebih memperhatikan sirkulasi udara antar ruang di dalam rumah, sinar matahari yang cukup di dalam rumah, serta kebersihan rumah tetap terjaga.

\section{UCAPAN TERIMA KASIH}

Tim Pengabdian masyarakat Fakultas Teknik Universitas Kadiri berterimakasih atas kontribusi pendanaan dari: alumni Universitas Kadiri, civitas akademik dan semua pihak yang tidak bisa disebutkan satu persatu

\section{DAFTAR PUSTAKA}

Hendy., Rahmawati, A \& Sujarwo. 2018. Program Kejar Paket ++ di Pusat Kegiatan Belajar Masyarakat (PKBM) di Kelurahan 
Gayam dan Bandar Lor Kecamatan Mojoroto Kota Kediri. Jurnal ABDIMAS Unmer Malang. Vol 3. Edisi Khusus, 1-3 pp.

Herlan, E., Sikwan, A., Hasanah, Bayuardi, G., Listiani, E.I \& Yulianti. 2020. Keterlibatan Akademisi dalam Menanggulangi Dampak COVID-19 Terhadap Masyarakat Melalui Aksi Berbagi Sembako. JCES Journal Of Character Education Society. Vol 3. 267-277 pp.

Nima, F. 2020. Pencegahan Primer Membentuk Masyarakat Sehat di Era COVID-19. SALAM Jurnal Sosial dan Budaya Syar'i. Vol 7 (10).

Syafrida, R.H. 2020. Bersama Melawan Virus COVID-19 di Indonesia. SALAM: Jurnal Sosial dan Budaya Syar'i. Vol 7 (6). 495-508 pp.

Tabi'in, A. 2020. Perilaku Hidup Bersih dan Sehat (PHBS) pada Anak Usia Dini sebagai Upaya Pencegahan COVID-19. Jurnal Edukasi AUD. Vol 6 (1). 58-73 pp.

Tempo.co. 2020. Wabah Corona Mempengaruhi 7 Tren Desain Rumah Terutama Faktor Higienis. Diakses pada 19 April 2020, dari: https://cantik.tempo.co

Zukmadini, A.Y., Karyadi, B \& Kasrina. 2020. Edukasi Perilaku Hidup Bersih dan Sehat (PHBS) dalam Pencegahan COVID-19 Kepada Anak-Anak di Panti Asuhan. Jurnal Pengabdian Magister Pendidikan IPA. Vol 3(1). 68-76 pp. 